\title{
108 電子ビーム微細加工技術の現状とその応用
}

The present condition of the electron beam micro-processing technology and its applications

$$
\text { ○田ロ 佳男 （エリオニクス） }
$$

Yoshio TAGUCHI, ELIONIX Inc., 3-7-6, Motoyokoyama-cho, Hachioji-shi, Tokyo

\begin{abstract}
At present, it is afraid of a limit of photolithography in the semiconductor field again to the requirement of which becomes rapidly minute electron beam lithography technology attention. As for the field as well, downsizing is the flow of the necessity as well as this except for the micro-machine which advanced micro-machining technology should lithography be necessary, the optical communication and so on we development research and development electron beam device use. So, the outline of the development device, an application example, and so on are shown about the study on the various adaptation fields that we advance it at present that report.
\end{abstract}

Key Words: Electron beam lithography, High accelerating voltage, Field emission, Spot beam, Direct writing

\section{1. 緒言}

現在、半導体分野では急激な微細化の要求に対し、フォ トリソグラフィーの限界が䁘念されており、電子ビーム露光 技街が再び注目を篹めている。また、これと同様に高度な微 細加工技術を必要とするマイクロマシン、光通信などのハイ テク分野においても、ダウンサイジングが必然の流れであり、 機械的な加工法から電子ビーム露光プロセスを取り入れた 加工法への転換が徐々に進行している。しかしながら、電子 ビーム露光装置といえば、半道体生産用の非常に高価な装置 をイメージし、またー方、研究用の電子ビーム露光装置では、 各種デバイスの試作や高付加価值製品の少量生産などの試 みに際し、性能面で対応できない埸合が多い。このような現 状を鑑み、我々は、扱い易くコストパフォーマンスに櫌れる 研究開発用電子ビーム露光装置の開発を行った。本報では、 現在我々が進めている様々な適応分野への取り組みについ て、開発装置の特長やアプリケーション例などを示し、その 報告を行う。

\section{2. 開発装置の概要}

图 1 に我々が開発を行った高加速電界放射型電子ビーム 露光装置（ELSー7700型）の外観を示す。

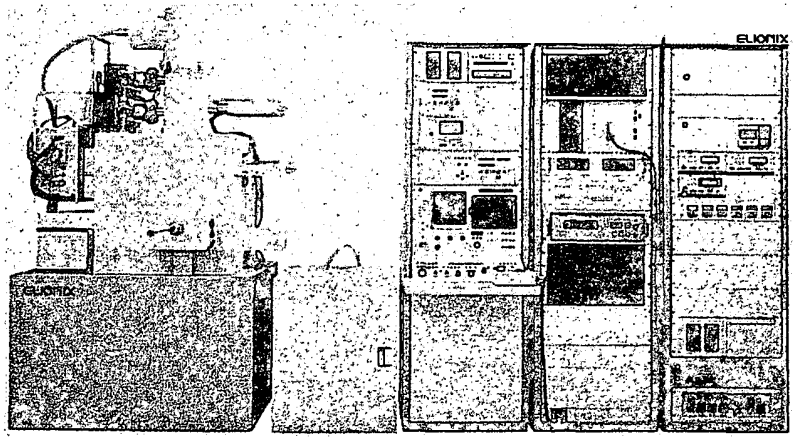

Fig.1 Field emission electron beam lithography system

通常、電子ビーム露光とは、半䕗体ウェハーやメタルマス クなどの基盤表面に電子線レジストを厚さ500 n m以下 に薄くスピンコートし、電子ビームを照射して感光させ、C AD入力された微細な図形パターンを高精度で転写する技 術である。照射される電子ビームの形態には、スポットビー ムや成形ビームなどがあり、微細加工用には前者が用いられ る。本装置で得られる最小スポットビーム径は $2 \mathrm{n}$ m以下で あり、また、最大 $75 \mathrm{k}$ Vの加速電圧により、シャープなエ ッジ形状を持つアスペ.クト比の高い微細パターンが得られ る。図 2 に、市販のポジ型電子線レジストを用いで描画を行 った幅 $8 \mathrm{n}$ m孤立ラインの断面 S EM写真を示す。また、表 1 には、本装置の主な壮様を示す。

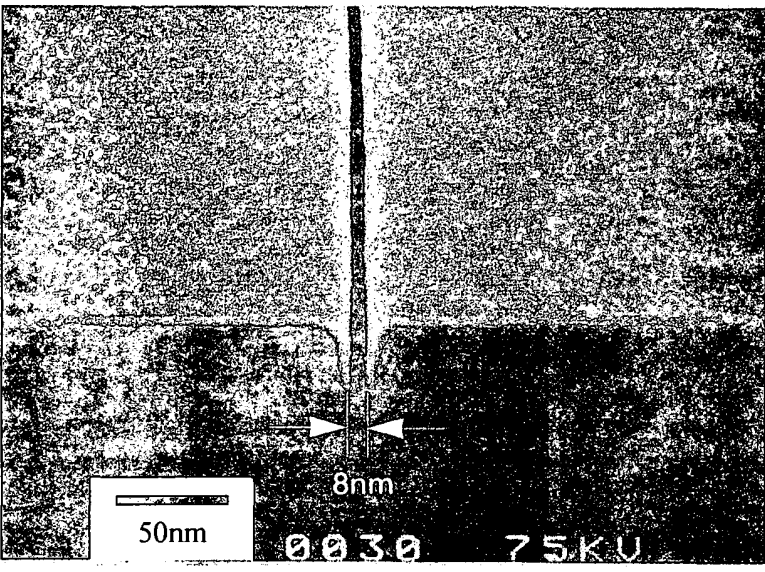

Fig.2 Cross-section of $8 \mathrm{~nm}$ line

\begin{tabular}{||c|c||}
\hline ITEM & SPECIFICATION \\
\hline Emitter & ZrO/W (TFE) \\
\hline Beam blanker & Electrostatic \\
\hline Magnetic lens system & 3 electromagnetic lenses \\
\hline Beam scanning & Electrostatic \\
\hline Lithography method & Vector scan, Raster scan \\
\hline Accelerating voltage & $25 \mathrm{kV}, 50 \mathrm{kV}, 75 \mathrm{kV}$ \\
\hline Electron beam shape & Round with gaussian distribution \\
\hline Electron beam diameter & $\Phi 2 \mathrm{~nm}($ Min) \\
\hline Electron beam current & $5 \times 10^{-13} \sim 1 \times 10^{-9} \mathrm{~A}$ \\
\hline Scanning field & $2,400 \mu \mathrm{m} \times 2,400 \mu \mathrm{m}($ Max) \\
\hline Beam positioning & $240,000 \times 240,000$ dots $(\mathrm{Max})$ \\
\hline Exposure area & $\mathrm{X}-150 \mathrm{~mm}, \mathrm{Y}-145 \mathrm{~mm}$ \\
\hline Work stage system & Step and repeat \\
\hline Stage driving motor & Stepping motor \\
\hline Laser interferometer & $\begin{array}{c}\text { Measures in } 0.6 \mathrm{~nm}(\mathrm{X}, \mathrm{Y}) \\
\text { Height sensor } 0.5 \mu \mathrm{m}(\mathrm{Z})\end{array}$ \\
\hline Stitching accuracy & $60 \mathrm{~nm}(3 \sigma)$ \\
\hline Work piece size & Wafer 6" (Max) \\
Mask 5" (Max)
\end{tabular}

Table.1 System specifications 


\section{3. 本装置の特長}

以下に主な技術上の特長を列挙する。

（1）熱電界放射型の電子銃を搭載しており、ビーム照射電 流を大きく設定してもビーム径の変化が小さく、ま た、長時間に渡り電流が安定している。

(2) 電子ビームの加速電压を最大で $75 \mathrm{kVV}$ 設定でき、 後方散乱電子の影留を小さくすることで高アスペク ト比のパターンニングが可能である。

（2）ズーム式レンズの採用により、ビーム照射電流量を变 化させてもフォ一カスに影響を与えることがなく、 また、対物レンズの発熱を一定に保持できるため、 温度ドリフトによる描画位置ズレを防止できる。

（4）レンズ系アライメンントに電磁方式を採用し、機械加工 精度では得られない最良のアライタント調整が行え るようにした。また、アライタント調整を含む電子光 学系の最適な条件設定值をメモリーすることでレシ ピ化し、随時再現できるようにした。

（5）レーザーにより、描画位置毎に基盤表面の高さ検出を 行うことで、フォーカスほけを解消し、基盤のそりや ステージ傾斜に関係なく広䉇囲において安定した露 光結果が得られる。

4. アプリケーション例

本装置の代表的なアプリケーションには、極微細パターン 露光、厚膜レジストを用いての高アスペクト比露光、ハーフ トーン露光などがある。電子ビーム露光法の問題点として、 後方散乱電子の影響、近接効果の影響などが挙げられるが、 これらの問題は、加速電圧を高めることで㪕減することが可 能である。
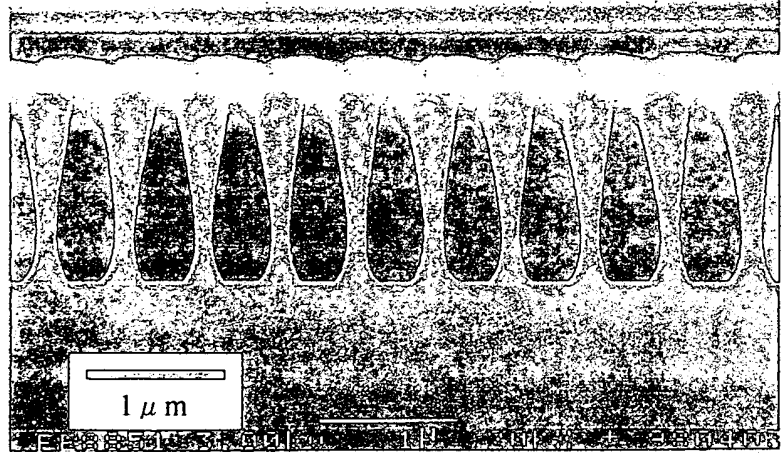

Fig.3 Cross-section of $0.3 \mu \mathrm{m}$ line and space pattern at $30 \mathrm{kv}$

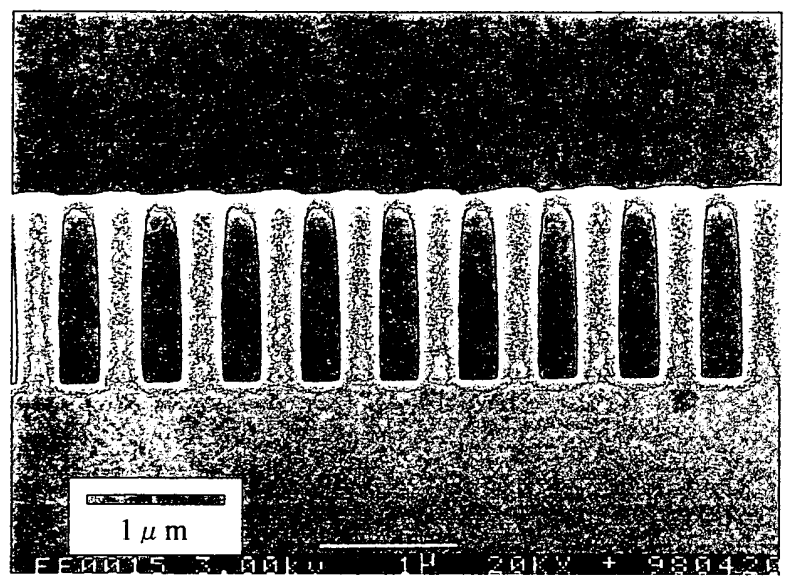

Fig.4 Cross-section of $0.3 \mu \mathrm{m}$ line and space pattern at $75 \mathrm{kv}$
图 3は、通常より厚い1.5 $\mu \mathrm{m}$ 膜厚のレジストに対し加速電 圧 $30 \mathrm{kV}$ で0.3 $\mu \mathrm{m}$ ライン\&スペースを描画した結果で あり、图4の加速電圧 $75 \mathrm{kV}$ で描画した結果と比較すると 後方散乱電子の影響により、エッジ形状殥度を悪くしている のがわかる。また、图 5、图6は、段階的に露光量を变化さ せたハーフトーン描画例であり、マイクロレンズなどへの応 用が期待されている。以上のように、形状稳度を向上させ、 また、局所的な露光量のコントロールを行うことで、䉓子ビ 一ム露光技術においても微細な三次元输造体を創生するこ とが可能になってきている。

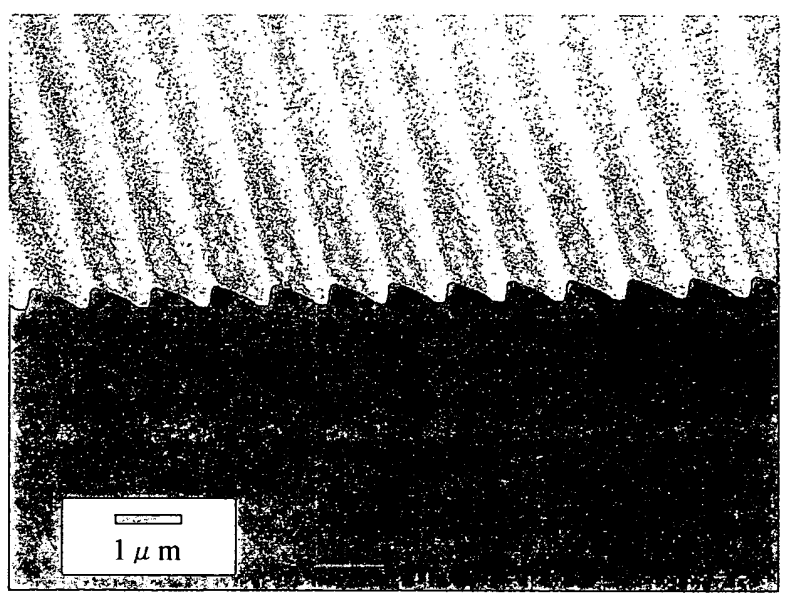

Fig.5 Cross-section of $1.0 \mu \mathrm{m}$ pitch brazed grating pattern

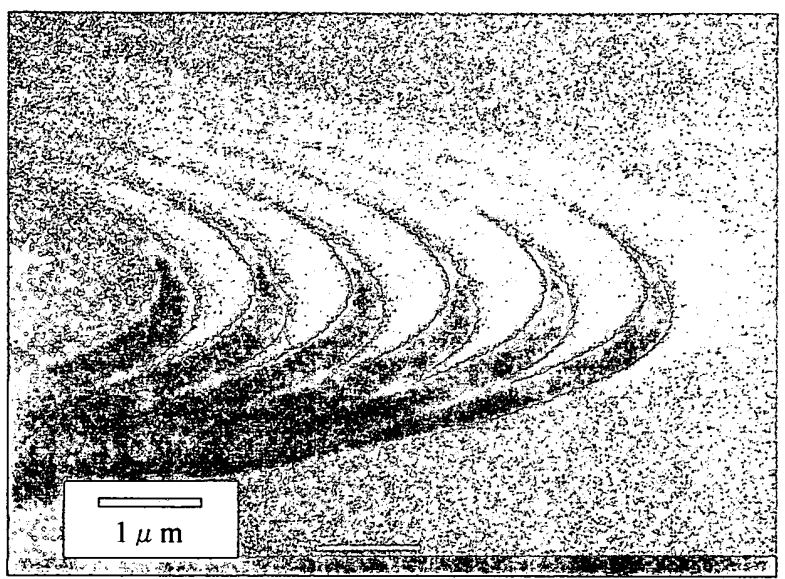

Fig.6 $1.0 \mu \mathrm{m}$ pitch circle brazed grating pattern

\section{5. 結言}

従来型の電子ビーム露光装置では、2 次元パターンの転写 がその主な役割であったが、我々が開発した装置では、加適 電圧を高めることで、より微細に、またよりアスペクト比の 高い加工が期待でき、積極的に 3 次元加工を行うことで多彩 なアプリケーションが可能になってきた。また、前述のよう に、フォトリソグラフィーでの限界を感じている分野や、高 付加価値製品の少量生産を目的とした場合、以前は、スルー プット、コスト、プロセス技術の確立などの諸問題から敬遠 されていた電子ビーム露光技術であるが、フォトマスクなど が省略できることも手伝い、既に、スポットビーム方式の本 装置を用いて、波長多重光通信システムにおけるWDMデハ イス、S AWデバイス、マイクロレンズなどの微細パターン の直接描画、所謂直描による生産が行われている。その他に も、ゲノム解析用マイクロチップ、次世代型HDD、同DV Dなどの分野における期待も大きく、新しいニーズにいち早 く対応したアプリケーション技術の確立、装置開発が今後の 㹎題である。 